\title{
Administrative Justice as Human Right: A Perspective from South Africa
}

\author{
Kolapo Omidire \\ Faculty of Law, Lead City University, Ibadan, Nigeria
}

\section{Email address:}

omidirelcuibadan@gmail.com

\section{To cite this article:}

Kolapo Omidire. Administrative Justice as Human Right: A Perspective from South Africa. International Journal of Law and Society. Vol. 4, No. 2, 2021, pp. 128-139. doi: 10.11648/j.ijls.20210402.20

Received: May 4, 2021; Accepted: May 25, 2021; Published: June 9, 2021

\begin{abstract}
Administrative justice should be a human right. However, it is not easily subsumed into the general body of human rights law because administrative law principles are largely procedural in character, hence, subject to domestic law. In some countries administrative justice is dependent on its development via common law by the courts, while in others is possible to have recourse to a constitutional provision permitting persons whose right is infringed by state action to seek constitutional redress. The article discusses administrative justice as a human right under the South African Constitution with a view to showing potential learning experience for other jurisdictions, and to possibly provide knowledge as to how best the legal framework pertaining to administrative justice could be developed to strengthen the protection of rights violated by action of government or those acting on its behalf. In South Africa, the Constitution and the PAJA constitute the source of the right to just administrative action while the common law ceases to have effect and will continue to inform the content of administrative law and other aspects of public law. The article shows how the Constitutional Court is empowered to develop the common law in relation to the application of the Bill of Rights to natural or juristic persons. The article concludes that constitutional and statutory provisions are available to facilitate the enforcement of the right to just administrative action, ensuring that every person "has the right to approach a court, alleging that a right in the Bill of Rights has been infringed or threatened, and the court may grant appropriate relief.'
\end{abstract}

Keywords: Administrative Justice, Human Right, Just Administrative Action, Judicial Review, South Africa

\section{Introduction}

One of the important objectives of administrative law is to protect the dignity of man. [1] The value of human dignity is applied in the interpretation of constitutional right to equality, [2] and ensuring that the right to be treated equally before the law is guaranteed by a demand that government action be undertaken only in accordance with the law. If equality cannot be guaranteed, the resultant arbitrariness of state action is likely to subject people to indignity. To achieve the objective that everyone is equal before the law, judges are conferred with authority to pronounce decisions and actions as invalid if an administrator or an agency of government transcends the limits of constitutional or parliamentary authority. [3] The scope of administrative law, however, transcends judicial review, extending to state regulation, the exercise of discretion, the provision of public information and the promotion of accountability and control. [4] These prerequisites are reflected in the grounds for which judicial review of administrative action is undertaken and are generally classified under three principles namely, illegality, irrationality, and procedural impropriety. [5] Administrative law in action therefore addresses questions relating to administrative decision-making powers, [6] making them susceptible to legal challenge to determine whether or not they are lawful, reasonable or procedurally fair. [7]

Regrettably, it has not been easy to subsume the concept of administrative justice into the general body of human rights law. This is because administrative law principles are largely procedural in character, and procedure is largely subject to domestic law. [8] Furthermore, the concept of global administrative justice is not only difficult, it is also controversial. There is a lack of consensus regarding the primary actors, the extent of its domain, whether its principles would invade national legal and constitutional space, and which extra-territorial authority will keep that power 
subjected within legal bounds to protect the citizens against abuse. [9]

In some countries like Nigeria, administrative justice is dependent on the development of the common law by the courts. Section 6 of the Constitution of the Federal Republic of Nigeria 1999 vests the judicial powers of the federation in courts created by that Constitution, by virtue of section 6 (6) (b) which extends the powers inter alia, to all matters '... between government or authority and to any persons in Nigeria, and to all actions and proceedings relating thereto, for the determination of any question as to the civil rights and obligations of that person.' The implication of this is that authority for the enforcement of administrative justice is dependent on the decisions of the courts in each case subject to the doctrine of judicial precedent. An alternative to the development of administrative law by precedent is the possibility of a reference to a particular section of a constitution or legislation, which gives authority to persons whose right is infringed by state action, to seek constitutional redress. This is the case under section 33 of the Constitution of the Republic of South Africa, 1996, [10] the objective of which is to subject the exercise of state power to constitutional control through legislation, such that when administrative acts affect or threaten the rights of individuals, there lies a recourse to the constitutional standards of administrative justice. [11]

The thrust of this paper is to demonstrate that administrative justice is a human right, which is intrinsic to a person by virtue of being human. [12] Part 2 of the paper will examine the nature of administrative justice vis-à-vis its qualification as a direct subject of human rights. Part 3 discusses administrative justice as a human right under the South African Constitution 1996, with a view to showing potential learning experience for other jurisdictions and possibly provide knowledge as to how best a legal framework pertaining to administrative justice could be developed to strengthen the protection of procedural rights in general. Part 4 of the paper engages in an assessment of the issues discussed and conclude with recommendations.

\section{Nature of Administrative Justice}

Administrative justice provides a mechanism to ensure that the exercise of public power complies with standards of rationality. [13] The demand for rationality in the exercise of governmental power via administrative justice stimulates the values of openness, fairness and accountability in governance in the public sphere. [14] However, the reach of administrative law into the private sphere may be resisted on the argument that such an extension is likely to interfere in the working mechanism of a free market. [15] Indeed, earlier decisions of the courts tend to suggest that the limitation on the exercise of public power by the courts to control arbitrariness does not extend to the private sphere. [16] There is however a need to challenge that assumption because the drive for efficiency and competitive practices have blurred the divide between private and public enterprises. [17]

Hoexter observes that the exercise of public power or the performance of a public function lies at the very centre of administrative law, and it comes up in different contexts, ranging from privatisation to the nature of an action, or the extent or reach of administrative fairness. [18] While acknowledging the difficulty associated with defining administrative law, the learned author sees the necessity for conceptualisation to give it focus. She argues that administrative law is the branch of the law concerned with the regulation of 'the organisation of the administrative institutions and the fairness and the efficacy of the administrative process, [which] govern the validity of and liability for administrative action and inaction and govern the administrative and judicial remedies relating to such action and inaction.' [19]

From the perspective of bureaucrats, an evaluation of administrative decision-making is seen as a threat on the belief that the government knows best in conferring authority on administrators, [20] hence, they have no need to justify their action or for their action to be reviewed. [21] As for vulnerable persons on the other hand, when a right or interest is at stake in an administrative proceeding compared to a judicial one, [22] the question is whether or not administrative justice could effectively protect that right or interest. Addressing these challenges is the central purpose of administrative justice which is to ensure that the individual affected by government decision-making process or the decision itself, gets justice. [23] To achieve that objective effectively requires the promotion of three different ideologies underlying the success of administrative justice as human right. These are the protection of private interests, which is the traditional common law approach to the role of law, the advancement of public interests, which is the orthodox public administration approach to the role of law, and thirdly, to aid the cause of public participation in decision-making. [24]

However, given that a challenge of administrative action is a call for restraint of the exercise of unjust public power, administrative justice may be conceived as restraint. This is far from the truth. The function of administrative justice is to clarify the objectives of a legislation and establish the norms required to realise those objectives by first, empowering the administrator to be effective and secondly, to establish controls on the acts of the administrative agency. [25]

In international law, the development of global administrative law (GAL) stems from the fact that development has a bearing on various actors, ranging from the state to the investor, and individuals in the community. [26] There is however a common understanding that the applicable rules for extra-territorial administrative justice cannot toe the line of classical international law, which is premised on the rules designed to address inter-governmental relationship. [27] Consequently, GAL operates against the background of the rule of law, enunciating a set of due process principles including the right to make representations and to be heard by the adjudicator, as well as to reasoned decisions. [28]

The success of GAL is however significantly impeded by some principles, which has advanced its course in other areas. For example, the inclusion of due process clauses common in international instruments resulted in the development of a 
universal rule of procedure in international law that a claimant of right in an international tribunal must first exhaust any local remedy available to him. [29] The rule found its way into domestic law relating to the control of exercise of public power that when an administrative decision or action is challenged, internal review must take place as precursor to an independent and impartial external review. [30] Unfortunately, the adoption and application of these principles in GAL appear to give fortuitous opportunity to recalcitrant states unwilling to submit to the jurisdiction of tribunals with extra-territorial jurisdiction. [31]

Nevertheless, the growing support for the recognition of individuals as rights-bearing subjects of international law in the protection of human rights is beginning to provide a basis for a varied application of the principle compared to that in general international law. Peculiar interests arising from alleged violation of rights of individuals, should necessitate greater recognition being given to human rights, different from those of international law. [32] Moreover, it would appear that the requirement to exhaust local remedies was not originally intended to apply to breaches of human rights, hence, the limitation to the application of the principle in some instruments to ensure that victims of human right abuse get access to justice. [33] In any event, international courts tend to apply the rule 'with some degree of flexibility and without excessive formalism, given the context of protecting human rights.'[34] Notwithstanding a lack of legislation or constitutional Bill of Rights, the function of administrative justice is to demand that governmental action is carried out in good faith with a rational appreciation of a purpose which is not meant to be 'arbitrarily and illegally attempting to divest a citizen of an incident of his civil status [especially considering that] no legislative Act can, without express language, be taken to contemplate an unlimited arbitrary power exercisable for any purpose.' [35] The courts therefore have a duty to interpret delegated legislation and consider administrative action in the reflective light of human right.

The requirements of administrative justice facilitate effective administration of laws affecting diverse matters that are usually of importance to the welfare, livelihoods and liberty of the people affected. To do that effectively, the values associated with legality, fairness and rationality are added to values associated with governance like transparency, accountability, consultation, input participation and efficiency, which are then incorporated into administrative justice. [36] Matters of this nature are better addressed in a constitutional framework subjecting the exercise of power to essential tools for the realisation of procedural justice which is assured when citizens have a right of access to seek justice through the courts of law. [37]

\section{A Perspective from South Africa}

The quest to ensure that there is no recurrence of the arbitrariness which characterised the erstwhile apartheid regime in South Africa resulted in an agitation for constitutional guarantees in the form of codification of administrative law in South Africa. While other sections of the Constitution and other statutes may be relevant in enforcing the right to just administrative action, section 33 of the Constitution states that:

1) Everyone has the right to administrative action that is lawful, reasonable and procedurally fair.

2) Everyone whose rights have been adversely affected by administrative action has the right to be given written reasons.

3) National legislation must be enacted to give effect to these rights, and must:

a) Provide for the review of administrative action by a court or, where appropriate, an independent and impartial tribunal;

b) Impose a duty on the state to give effect to the rights in subsections (1) and (2); and

c) Promote an efficient administration.

Accordingly, section 33 (1) and (2) of the Constitution enumerates four requirements of the right to just administration, namely lawfulness, reasonableness, procedural fairness and the provision of reasons, [38] while section 33 (3) of the Constitution envisages that a legislation to be enacted will facilitate the practical implementation of the right, and provide the procedures and the statutory mechanisms to make the realisation of the right a reality. [39] The Promotion of Administrative Justice Act 2000 [40] (hereafter "the PAJA") is the legislation envisaged, and as clearly stated in its explanatory note, it is 'to give effect to the right to administrative action that is lawful, reasonable and procedurally fair and the right to written reasons for administrative action as contemplated in section 33 of the Constitution ... and to provide for matters incidental thereto.' The PAJA is considered in the succeeding paragraphs of this part of this article.

\subsection{The PAJA}

The essence of the PAJA is to comply with the constitutional requirement in section 33 (3) by creating the means to give effect to the right to just administrative action. The PAJA is usually construed from the perspective of the control of the exercise of public power, and rightfully so, because taken from the perspective of section 33 (1) and (2) of the Constitution, the exercise of power and decision-making that is fair, rational and lawful highlights the underlying protection of the human right to just administrative action. [41] However, a less commonly acknowledged objective is the obligation created by statute, which is to promote an efficient administration [42] as expatiated in the preamble to the PAJA. [43] This highlights the need to subject public administration to one of the overarching values specified in section 1 of the Constitution, namely 'to ensure accountability, responsiveness and openness.' [44] The fulfilment of the attributes of the values will significantly eliminate potential abuse of the right protected by section 33 of the Constitution. Being the national legislation envisaged by section 33 of the Constitution addressing the four heads of the right to just administrative action, the PAJA is intended to be a codification of the human 
right to administrative justice in South Africa. Administrative justice is therefore regulated by only one system of law grounded in the Constitution, and the powers of the court flow from the PAJA and perforce, the Constitution itself. [45] The constitutive elements of the right to administrative justice in section 33 of the Constitution are considered in the following paragraphs.

\subsection{Administrative Action}

Any decision, which is the subject of an enquiry or determination under the PAJA must be an administrative action. The question may be asked as to what constitutes 'administrative action' under the PAJA? [46] In an action for the enforcement of section 33 of the Constitution, that inquiry becomes 'what is the administrative act sought to be reviewed and set aside? Absent such an act, the application for review is still-born. [47]

A decision, which constitutes 'administrative action' within the contemplation of section 1 of the PAJA must relate to the source and nature of the decision. [48] However, regardless of the identity of the maker of the decision, what is required is whether or not he was exercising a public power or performing a public function? [49] Such decision will extend to those taken by bodies exercising public power, [50] including the exercise of discretion, [51] the process of a government tender, [52] compulsory arbitration proceedings in terms of the Labour Relations Act 66 of 1995 (LRA), [53] and actions taken by public corporations with the status of organs of state. [54] The focus is not on the arm of government to which the actor belongs. Rather, the focus is on the nature of the power the actor is exercising, thus, some acts of the legislature may constitute administrative action and judicial officers may from time to time carry out administrative tasks. [55]

There is a need for caution. A strict application of sections 3 and 4 of the PAJA to the definition of administrative action may have the effect of excluding certain circumstances, especially where the action does not 'materially affect the rights or legitimate expectations. [56] That effect may whittle down the scope of section 33 of the Constitution, which creates a right to just administrative action and sets the overriding conditions, namely action 'that is lawful, reasonable and procedurally fair. [57] An application of the right limited by the phrase 'materially affect the rights or legitimate expectations' may complicate potential application of the right in certain scope of administration where knowledge or an applicable science is still developing or controversial. [58] In Leon Joseph and Others $v$ City of Johannesburg and Others, [59] the Constitutional Court held that to materially affect the right of a person implies a significant and not trivial impact, which must have a 'direct, external legal effect" on the applicants.' [60] Any limitation of the section 33 right caused by a narrow interpretation of the right by the PAJA and resulting in such constraining consequences should not be applied. [61]

Mindful of the challenge, it would appear that the Supreme Court of Appeal (hereafter "the SCA") recognised that the definition of 'administrative action' in section 1 of the PAJA is cumbersome and capable of creating a number of terms that are themselves overlapping and which may affect or limit its meaning or scope. In Greys Marine Hout Bay (Pty) Ltd and Others $v$ Minister of Public Works and Others, [62] the SCA proffered a definition which consolidates the principal elements provided in the PAJA to read as follows:

...administrative action means any decision of an administrative nature made... under an empowering provision [and] taken... by an organ of state, when exercising a power in terms of the Constitution or a provincial constitution, or exercising a public power or performing a public function in terms of any legislation, or [taken by] a natural or juristic person, other than an organ of state, when exercising a public power or performing a public function in terms of an empowering provision, which adversely affects [63] the rights of any person and which has a direct, external legal effect.

Given that the focus is on the function rather than the functionary, [64] the action of a private person or entity exercising public power or performing a public function could be subsumed within the scope of administrative action in terms of the PAJA. [65] Accordingly, the action of 'a natural or juristic person, other than an organ of state, when exercising a public power or performing a public function in terms of an empowering provision, which affects the rights of any person and which has a direct, external legal effect...' [66] as contemplated by the PAJA may be actionable. The decision in the case of Mobile Telephones Networks (Pty) Ltd v SMI Trading CC [67] is instructive. The appeal was to resolve whether or not section 22 of the Electronic Communications Act [68] (ECA) infringes section 25 of the Constitution. The appellant had unilaterally decided the terms on which it would continue to occupy the respondent's property pursuant to section 22 (1) of the ECA which gives an electronic communications network power inter alia to 'enter upon any land, including any street, road, footpath, or land reserved for public purposes...' The court held that any decision by the applicant in terms of section 22 of the ECA is 'administrative action,' which in any event, must be procedurally fair, the effect of which is to give due regard to applicable law and the environmental policy of the republic, as the Constitution does not countenance arbitrary action. Therefore, the exercise of public power by a private entity constitutes administrative action under the PAJA, which by necessity attracts fundamental rights vested in a person affected to administrative action that is lawful, reasonable and procedurally fair. [69]

\subsection{Reasons for Administrative Action}

The PAJA addresses the issues associated with reasons for administrative action in section 5. Under the PAJA, a person whose rights have been materially and adversely affected by administrative action has a right to be given reasons for the action, failing which he can within 90 days of becoming aware of the action or when he might reasonably be expected to have become aware of the action request to be furnished with written reasons. [70] Non-compliance leads to a presumption in subsequent judicial review proceedings that the 
administrative action was taken without reason. [71] Though an administrator may depart from the requirement to provide reasons, any departure must be reasonable and justifiable in the circumstances, and the requester must be informed of the departure. [72] An indication that a decision or action is at the discretion of the decision-maker is not an acceptable reason. [73]

In Logbro Properties CC $v$ SA Bedderson, NO and Others, [74] the appellant had signed tender documents which included a clause that a public authority could take action without giving reasons. Upon a subsequent challenge, it was contended that the authority cannot be compelled to give reasons because its decisions constituted a binding contract on those who executed it based on the terms of the tender. The SCA disagreed, holding that notwithstanding the contractual relationship, the principles of administrative justice apply to the public authority's exercise of public power. The SCA held that the tender process constituted an administrative action, which entitled the complainant to a lawful and procedurally fair process and outcome. Therefore, the terms of a contract must yield for the authority to comply with its public duties under the Constitution and any applicable legislation. [75]

\subsection{Judicial Review of Administrative Action}

Section 2 of the Constitution lays the foundation for legal control of public power, providing that the Constitution is the supreme law of the Republic, and any law or conduct inconsistent with its provisions is invalid. This view is amplified by the decision of the Constitutional Court in Fedsure Life Assurance Ltd and Others $v$ Greater Johannesburg Transitional Metropolitan Council, [76] emphasising that the doctrine of legality is an incident of the rule of law, which is:

... central to the conception of our constitutional order that the Legislature and the Executive in every sphere are constrained by the principle that they may exercise no power and perform no function beyond that conferred upon them by law. At least in this sense, then, the principle of legality is implied within the terms of the interim Constitution.

By implication, any administrative action which fails to conform to constitutional or the PAJA requirements is invalid and may be set aside. Section 1 (c) of the Constitution emphasises that the 'supremacy of the Constitution and the rule of law' are some of the values on which the South African democracy is based. Therefore, courts are under an obligation to declare any law or conduct that is inconsistent with the Constitution as invalid to the extent of its inconsistency.' [77]

Aside the PAJA, there are other methods to seek redress for wrongs attributable to the adverse effect of administrative action. For example, section 182 (1) of the Constitution gives power to the Public Prosecutor to inter alia 'investigate any conduct ... in the public administration in any sphere of government, that is alleged or suspected by to be improper or to result in any impropriety or prejudice.' Similarly, section 184 (2) of the Constitution empowers the South African Human Rights Commission 'to investigate and report on the observance of human rights; to take steps to secure appropriate redress where human human rights have been violated; to carry out research and to educate.' Furthermore, the exercise of public power may require justification in certain situations. The courts provide a veritable site for the justification of public conduct. [78] Specifically however, the PAJA permits any person to 'institute proceedings in a court or a tribunal for the judicial review of an administrative action.' [79]

A court or tribunal is empowered to review administrative action in a myriad of circumstances provided for in section 6 (2) and (3) of PAJA, and section 7 of the PAJA contains provisions for the procedure guiding the institution of action for judicial review. From these provisions, the court seised of a matter of judicial review of administrative action is to determine whether or not an irregularity has occurred, as it is only upon the occurrence of illegality that the action must be 'legally evaluated to determine whether it amounts to a ground of review under the PAJA.' [80] Simply put, the essence of judicial review is to detect and correct maladministration. [81]

In Western Cape Minister of Education and Others $v$ The Governing Body of Mikro Primary School and Another, [82] the SCA held that a refusal to change the language policy in a public school is an administrative action which is subject to review; and should the decision be unreasonable in the sense that no reasonable person would in the circumstances have refused to change the language policy, it may be reviewed and set aside. [83] In ruling whether or not an administrative decision is reasonable, guidance is provided in section $6(2)(\mathrm{h})$ of the PAJA, which requires that the decision must not be 'so unreasonable that no reasonable person could have so exercised the power.' [84] In that regard, the Constitutional Court held that a breach of section 6 (2) (h) of the PAJA can be shown inter alia by a proof that:

... the decision was arrived at arbitrarily or capriciously or mala fide or as a result of unwarranted adherence to a fixed principle or in order to further an ulterior or an improper purpose; or that [the decision-maker] misconceived the nature of the discretion conferred upon him and took into account irrelevant considerations or ignored relevant ones; or that the decision... was so grossly unreasonable as to warrant the inference that he had failed to apply his mind to the matter in the manner aforestated. [85]

In interpreting 'reasonableness' of administrative decision, section 39 (2) of the Constitution provides a guide that every court, tribunal or forum must promote the spirit, purport and objects of the Bill of Rights. [86] Accordingly, section 6 (2) (h) of the PAJA must be interpreted through the prism of the Bill of Rights. [87] Furthermore, it is important to note that the Bill of Rights 'attach to every person and are enjoyed everywhere in the country, except where they are limited in terms of section 36 of the Constitution.' [88] For any limitation of the rights to be justified under section 36 , it must be authorised by a law of general application rather than some vague rules. [89]

In the same vein, an administrative action may be set aside where the administrator fails to take a decision which is required, delays in taking the decision, or takes the decision outside the period stipulated therefor. [90] For example, in 
Minister of Environmental Affairs and Tourism and Another $v$ Scenematic Fourteen (Pty) Ltd, [91] the court held that discretion vested in a public functionary must be exercised by that functionary in the absence of the right to delegate. He must not become a mere 'rubber-stamp' relying only on the advice of others and without knowing the underlying basis for the advice such that it cannot be said that he exercised the power in question. Furthermore, it does not matter that legislation is devoid of an enumeration of the factors to be considered by the administrator in taking a decision. International law may be relevant in that regard. Section 233 of the Constitution provides that 'when interpreting any legislation, every court must prefer any reasonable interpretation of the legislation that is consistent with international law over any alternative interpretation that is inconsistent with international law.' [92]

In the same vein, a court or tribunal has the power to judicially review an administrative action if the action was taken based on irrelevant considerations, or relevant considerations were not considered. [93] However, in reaching a decision, the court is not to usurp the decision of administrative agencies but to ensure that their decisions fall within 'the bounds of reasonableness as required by the Constitution.' [94] Other relevant considerations in the procedure for judicial review are stipulated in section 7 of the PAJA which requires that proceedings for judicial review must be instituted without unreasonable delay, [95] and that they can only commence after the exhaustion of internal remedies in terms of the PAJA or any other law. [96] Another relevant factor is the nature of remedies in proceedings for judicial review, [97] which are considered below.

\subsection{Remedies in Proceedings for Judicial Review}

Caution is the watchword in the consideration of administrative decision in judicial review as there is a need to maintain a reasonable balance between unfair decisions of public authorities and the desire to avoid undue judicial interference in public administration. [98] Care should be taken not to impose obligations upon the government which may constrain its ability to make and implement effective policy. [99] In this regard, procedural fairness must be distinguished from substantive fairness. The substantive fairness of a decision in itself is not a ground for judicial review otherwise, the court would be dragged into determining matters which are best dealt with at political or administrative level [100]

Section 8 of the PAJA gives a court or tribunal engaged in judicial review of an administrative action in terms of section 6 a discretion to 'grant any order that is just and equitable.' [101] In Makhanya NO and Another v Goede Wellington Boerdery (Pty) Ltd, [102] the SCA held that a decision constituting administrative action is reviewable in terms of section $6(2) \mathrm{h}$ ) of PAJA if it is one which a reasonable decision-maker ought not to reach. The court further held that section 8 (1) of the PAJA authorises the court 'in exceptional cases' [103] to set aside the administrative decision and substitute or vary it or correct a defect resulting from the action. [104] However, considering that the PAJA does not provide guidelines for the determination of 'exceptional cases,' any decision reached must satisfy the constitutional imperative that administrative action must be lawful, reasonable and fair. [105]

Where a violation of the right to procedural fairness is caused by a failure to comply with a peremptory requirement of the law, an administrative authority has no inherent power to condone the failure. [106] However, a court or tribunal in judicial review may condone the non-compliance where such condonation is not incompatible with public interest. Therefore, in Millennium Waste Management (Pty) Ltd v The Chairperson of the Tender Board: Limpopo Province and Another, [107] the SCA condoned the failure of the tender committee to comply with rules because it would promote the values of fairness, competitiveness and cost-effectiveness required in section 217 of the Constitution, resulting in the award of a tender to the appellant who had quoted the sum of R444 244.43 per month, against the successful tenderer's R3 642257.28 per month for the same service.

Finally, in exceptional circumstances, a court or tribunal in granting a just and equitable order is permitted to 'direct the administrator or any other party to the proceedings to pay compensation.' [108] This is in addition to the constitutional right to 'appropriate relief' in terms of section 38 of the Constitution. [109]

\subsection{Effect of Delay}

It is important that an application for review of an administrative decision should be brought within a reasonable time, as delay may prejudice to the other party. Delay may also adversely affect the public interest element in the finality of administrative action, thereby making the validity of decisions uncertain for the members of the public who may want to rely on those decisions. [110] Section 7 (1) of the PAJA requires that proceedings for judicial review must be instituted not later than 180 days of the conclusion of proceedings of internal remedies, or when the aggrieved person 'was informed of the administrative action, became aware of the action, and the reasons for it or might reasonably have been expected to have become aware of the action and the reasons.' The period of 180 days should ordinarily serve government's interests well to rethink its action if necessary and should afford an adequate and fair opportunity to an aggrieved person to seek judicial redress. [111]

Section 9 (1) of the PAJA, however, provides that the 180-day period 'may be extended for a fixed period, by agreement between the parties or, failing such agreement, by a court or tribunal, on application by the person or administrator concerned;' and such application may be granted where the interests of justice so require. [112] The question of whether or not delay in initiating judicial review proceedings is unreasonable is a question of fact, the determination of which is subject to the inherent jurisdiction of the court. It requires two considerations, namely, 'was there an unreasonable delay?' and 'if so, should the delay in all the circumstances be condoned?' [113] 


\subsection{Exhaustion of Internal Remedies}

Section 7 (2) of the PAJA provides that '... no court or tribunal shall review an administrative action in terms of this Act unless any internal remedy provided for in any other law has first been exhausted.' This rule is however subject to the proviso that 'a court or tribunal may, in exceptional circumstances and on application by the person concerned, exempt such person from the obligation to exhaust any internal remedy if the court or tribunal deems it in the interest of justice.' [114] The essence of the requirement to exhaust internal remedy is to allow the mechanism of the statute to be applied to rectify any perceived irregularities prior to resorting to litigation, thereby providing an immediate and cost-effective relief.

There is wisdom in allowing the administrator to fully complete his task before opportunity is given to the court to perform its review function. [115] To have it otherwise may result in premature judicial intervention and probably usurp executive role and function. In Petronella Nellie Nelisiwe Chirwa $v$ Transnet Limited and Others, [116] it was held that the fact that the applicant did not fully take advantage of remedies available to her under the applicable legislation, which required resolution by the Commission for Conciliation, Mediation and Arbitration (CCMA) in terms of section 191 (1) (a) (ii) of the Labour Relations Act 1995 [117] prior to approaching the High Court to establish her right under section 33 of the Constitution was fatal to her claim.

Meanwhile, internal remedies are to be taken as a conjunctive whole. Therefore, in the absence of a decision by a particular person or office, or dissatisfaction with a decision if one is made, the affected person must pursue the next line of decision-making, otherwise the whole process is compromised. [118] Furthermore, in arriving at a decision on exhaustion of internal remedies, rights must be compared and balanced carefully such that if necessary, public policy and public interest may override an applicant's rights. For example, in Radovan Krecjir $v$ The Minister of Correctional Services and Others, [119] one of the issues for determination by the court was whether or not the applicant had utilised and/or exhausted the internal remedies available to him in terms of section 21 of the Correctional Services Act 1998 [120] to address complaints or issues arising in the course of his incarceration. The court held that confiscation of the applicant's notebooks and documents in the course of a search of his cell in prison during which several illegal items including firearms were found, was necessary to enforce order in the prison and to protect other inmates.

While there appears to be a credible rationale for insisting on exhaustion of internal remedies, potential abuse cannot be ruled out especially if a potential applicant finds it impossible to exhaust internal remedies due to the uncooperative approach of a government functionary or agency. Simply put, does a wrongful application of section 7 (2) of the PAJA have an adverse impact on the effect of the enforcement of a right? This was the question before the Constitutional Court in
Wycliffe Simiyu Koyabe and Others v Minister for Home Affairs and Others. [121] The Court considered analogous situations in international law, observing that the view of the African Commission on Human Rights is that to be operative the local remedy must be 'available, effective and sufficient' to redress the complaint. [122] The African Commission had held in Jawara $v$ The Gambia [123] that:

... a remedy is considered available if the petitioner can pursue it without impediment, it is deemed effective if it offers prospect of success, and it is found sufficient if it is capable of redressing the harm complaint.

The Court further held that the effect of section 7 (2) (c) of the PAJA is to provide a relief to an aggrieved applicant in the event of a potential action by administrators to frustrate the necessity of judicial scrutiny of administrative action. Accordingly, the provision of section 7 (2) (c) of the PAJA facilitates exceptional circumstances in which a court can condone non-exhaustion of remedies and allow judicial review notwithstanding. As to what constitutes 'exceptional circumstances,' the Constitutional Court pointed out that it depends on the circumstances of each case, [124] but on the whole, the 'internal remedy must be readily available, and it must be possible to pursue [it] without any obstruction, whether systematic or arising from unwarranted administrative conduct.' [125]

\section{Conclusion}

Administrative action and administrative proceedings have a far greater impact on individual rights than regular judicial proceedings because the former is concerned with everyday practice of administrative justice. [126] Furthermore, poor and vulnerable persons, as well as communities face major challenges including access to legal knowledge and/or financial capacity required to enforce rights. While it is recognised that administrators are confronted with practical difficulties in implementing decisions, they should be held to account where their action infringes rights because remedy is supposed to be adapted to a right and not the right to a remedy. [127] In Bel Porto School Governing Body and Others $v$ The Premier of the Province and Another, [128] the Constitutional Court observed that the Constitution prohibits administrative action which among other things, adversely affects a disadvantaged sector of the community. In the words of Mokgoro and Sachs J,

... the Constitution prohibits administrative action which, however meritorious in general thrust, is based on exclusionary processes, applies unacceptable criteria and results in sacrifice being borne in a disproportionate and unjustifiable manner, the more so if those who are most adversely affected are themselves from a disadvantaged sector of the community. [129]

Though in South Africa, the Constitution and the PAJA constitute the source of the right to just administrative action, it does not imply that the common law ceases to have effect. Rather, as expatiated by the Constitutional Court in The Pharmaceutical Manufacturers Association of South Africa 
and Others - In re: the ex parte application of the President of the Republic of South Africa and Others [130] the common law is not a separate body of law distinct from the Constitution. There is only one system of law, and that is the Constitution, which is the supreme law from which all law, including the common law derive their authority. Therefore, the well-established principles of common law will continue to inform the content of administrative law and other aspects of public law and will contribute to its future development. The Constitutional Court is empowered and will continue to develop the common law in relation to the application of the Bill of Rights to natural or juristic persons. [131]

Judicial deference is recommended to deal with the tasks ordinarily undertaken by public authorities, and that in itself is consistent with the concerns for individual rights, especially in relation to complex administrative matters difficult for poor and vulnerable persons to appreciate quickly. Administrative action should not stimulate exclusionary processes or be applied in a manner that will result in any sacrifice arising therefrom being borne in a disproportionate and unjustifiable manner by those from a disadvantaged sector of the community. If the latter occurs, the courts should be open in every sense of the word, to allow victims to seek remedies. The cliché that the judiciary is the last hope of the common man is not lost on the draftsman of the Constitution. Section 38 of the Constitution provides inter alia that a person 'has the right to approach a court, alleging that a right in the Bill of Rights has been infringed or threatened, and the court may grant appropriate relief.'

To strengthen the constitutional democracy, independent state institutions like the Human Rights Commission and the Office of the Public Protector are created and made subject only to the Constitution and the law. The institutions are required to be impartial and to 'exercise their powers and perform their functions without fear, favour or prejudice.' [132] In the same vein, other constitutional provisions including those on access to information, [133] and access to courts, [134] support section 33 of the Constitution as procedural rights, to reinforce administrative justice as human right. Finally, section 195 of the Constitution sets out the basic values and principles [135] that must govern public administration, [136] and which must be promoted in national legislation, [137] including requirements that the public administration must be development-oriented, [138] accountable, [139] based on fairness, [140] and respond to people's needs. [141] These constitutional and statutory provisions are available to facilitate the enforcement of the right to just administrative action, and they confirm the robustness of South African law in guaranteeing administrative justice as human right.

\section{References}

[1] Dyzenhaus D "Dignity in administrative law: Judicial deference in a culture of justification" (2012) Review of Constitutional Studies 88 .
[2] De Vos P and Freedman W (eds) South African Constitutional Law in Context (Oxford University Press Cape Town 2014) 456. See also S v Makwanyane (1995) (3) SA 391 (CC) 144.

[3] Minister of Finance and Others v Van Heerden (2004) (6) SA $121(\mathrm{CC})$.

[4] Jones M "Administrative justice: Some preliminary thoughts on a (post) modern theoretical perspective" in Creyke R and MacMillan J (eds) Administrative Justice: The Core and the Fringe (Australian Institute of Administrative Law Inc Canberra 2000) 41 .

[5] Ramadhani ASL "Judicial review of administrative action as the primary vehicle for the protection of human rights and the rule of law" Paper presented to the Southern African Chief Justices Conference at Kasane Botswana on 7th-8th August 2009 available at https://www.venice.coe.int/SACJF/2009_08_BTW_Kasane/sp eeches/Ramadhani_Judicial_Review.pdf (date of use 5 March 2021).

[6] Glazewski J (2013) Environmental Law in South Africa (LexisNexis Durban 2013) 5-27.

[7] See Del Porto School Governing Body v Premier, Western Cape (2002) (3) 265 (CC) 84-90.

[8] Harlow C "Global administrative law: The quest for principles and values" (2006) European Journal of International Law 192.

[9] Harlow C "Global administrative law: The quest for principles and values" (2006) European Journal of International Law 187

[10] Hereafter "the Constitution."

[11] The President of the Republic of South Africa and Others v South African Rugby Football Union and Others (2000) (1) SA 1 (CC) 136.

[12] Mubanzigi JC "Towards a new approach to the classification of human rights with specific reference to the African context" (2004) African Human Rights Law Journal 94.

[13] Longley D and James R Administrative Justice: Central Issues in UK and European Administrative Law (Cavendish Publishing London 1999) 167.

[14] Thomas R and Tomlinson $\mathrm{J}$ "Mapping current issues in administrative justice: austerity and the "more bureaucratic rationality' approach" (2017) Journal of Social Welfare and Family Law 381.

[15] Jones M "Administrative justice: Some preliminary thoughts on a (post) modern theoretical perspective" in Creyke R and MacMillan J (eds) Administrative Justice: The Core and the Fringe (Australian Institute of Administrative Law Inc Canberra 2000) 47.

[16] An analysis of earlier decisions is available in Cartier G (2010) “The legacy of Roncarelli v Duplessis 1959-2009" McGill Law Journal 392.

[17] See Rowley CK Antitrust and Economic Efficiency (Macmillan, London, 1973) 8.

[18] Hoexter C Administrative Law in South Africa 2nded (Juta Cape Town 2012) 3.

[19] Hoexter C Administrative Law in South Africa 2nded (Juta Cape Town 2012) 2. 
[20] Historical antecedents of the doctrine of parliamentary supremacy in the UK prevents judges from declaring legislation as ineffective, as laws made by Parliament are not subject to review expect by itself. See Leyland P and Anthony G Textbook on Administrative Law (8thed) (Oxford University Press Oxford 2016) 1. However, contemporary understanding that the supremacy of the Parliament does not imply that it is morally entitled to do what it likes, as any legislation that does not enjoy popular support is lacking in moral authority See Bogdanor V "The consistency of Dicey: A reply to McLean and Macmillan" (2008) Public Law 19.

[21] Mason A "Delivering administrative justice: Looking back with pride, moving forward with concern" 2010 Australian Institute of Administrative Law Forum 5.

[22] Sossin L "Access to administrative justice and other worries" in Flood CM and Sossin L (eds) Administrative Law in Context (2nd ed) (Emond Montgomery Publications Toronto 2013) 502.

[23] Creyke R "Administrative Justice-Towards Integrity in Government" (2007) Melbourne University Law Review 705.

[24] [1] Craig "Three perspectives on the relationship between administrative justice and administrative law" in Creyke R and MacMillan J (eds) Administrative Justice: The Core and the Fringe (Australian Institute of Administrative Law Inc Canberra 2000) 31

[25] Craig "Three perspectives on the relationship between administrative justice and administrative law" in Creyke R and MacMillan J (eds) Administrative Justice: The Core and the Fringe (Australian Institute of Administrative Law Inc Canberra 2000) 32 .

[26] Dann P "The Global Administrative Law of development cooperation" in Cassesse S Research Handbook on Global Administrative Law (Edward Elgar Publishing Ltd Cheltenham 2016) 418 .

[27] Harlow C "Global administrative law: The quest for principles and values" (2006) EJIL 190.

[28] Stack KM "An administrative jurisprudence: The rule of law in the administrative state" (1986) Columbia Law Review 1994.

[29] Harlow C "Global administrative law: The quest for principles and values" (2006) EJIL 188.

[30] Creyke R “Administrative Justice-Towards Integrity in Government" (2007) Melbourne University Law Review 707.

[31] See for example, Cudjoe v Ghana (2000) AHRLR 127.

[32] D'ascoli 2007 The Rule of Prior Exhaustion of Local Remedies in the International Law Doctrine and its Application in the Specific Context of Human Rights Protection European University Institute Italy Working Paper Law No 2007/02 available http://cadmus.eui.eu/bitstream/handle/1814/6701/LAW 2007 02.pdf?sequence $=1$ (date of use 2 March 2021).

[33] For example, article 46 (2) of the American Convention on Human Rights 1969 provides that requirement for the exhaustion of local remedies shall not be applicable when.

[34] The domestic legislation of the state concerned does not afford due process of law for the protection of the right or rights that have allegedly been violated.

[35] The party alleging violation of his rights has been denied access to the remedies under domestic law or has been prevented from exhausting them; or

[36] There has been unwarranted delay in rendering a final judgment under the aforementioned remedies.

[37] Similarly, article 50 of the African Charter on Human and Peoples' Rights 1981 provides that the requirement for the exhaustion of local remedies shall not apply if it is obvious to the African Commission that 'the procedure of achieving these remedies would be unduly prolonged.'

[38] Council of Europe/ European Court of Human Rights Practical Guide on Admissibility Criteria 2019 available at https://www.echr.coe.int/Documents/Admissibility_guide_EN G.pdf (date of use 7 March 2021).

[39] The Canadian Supreme Court in Roncarelli v. Duplessis (1959) SCR 121 at 141.

[40] Anthony G "Administrative justice in the United Kingdom" (2015) Italian Journal of Public Law 13.

[41] Harlow C "Global administrative law: The quest for principles and values" (2006) European Journal of International Law 193.

[42] Minister of Health v New Clicks South Africa (Pty) Ltd and Others (2006) (2) SA 311 (CC) at para 143.

[43] Corder $\mathrm{H}$ "Administrative justice in the South African Constitution" (1998) Admin Review 7.

[44] Act 3 of 2000.

[45] Currie I and Klaaren $\mathrm{J}$ "Introduction to the Promotion of Administrative Justice Act" in 2001 The Promotion of Administrative Justice Act Benchbook (Siber Ink Publishers Cape Town 2001) para 1.2.

[46] Section 33 (3) (c) of the Constitution.

[47] To 'promote an efficient administration and good governance; and create a culture of accountability, openness and transparency in the public administration or in the exercise of a public power or the performance of a public function, by giving effect to the right to just administrative action.'

[48] See also the values and principles governing public administration listed in section 195 of the Constitution.

[49] See Fedsure Life Assurance Ltd and Others v Greater Johannesburg Transitional Metropolitan Council (1999) (1) SA 374 (CC) at para 32.

[50] ection 1 of PAJA provides that ... unless the context indicates otherwise, 'administrative action' means any decision taken, or any failure to take a decision, by:

[51] An organ of state, when-

a) exercising a power in terms of the Constitution or a provincial constitution; or

b) exercising a public power or performing a public function in terms of any legislation; or

[52] A natural or juristic person, other than an organ of state, when exercising a public power or performing a public function in terms of an empowering provision, which affects the rights of any person and which has a direct, external legal effect... 
[53] Gamevest (Pty) Ltd v The Regional Land Claims Commissioner for the Northern Province and Mpumalanga (2002) ZASCA 117 at para 11. In Mzamba Taxi Owners' Association and Another v Bizana Taxi Association and Others (2005) ZASCA 74 (SCA), the appellants contended that permit to operate route was issued irregularly, thereby adversely affected the interests of its members financially. The court held that there was no administrative action because the Provincial Taxi Registrar merely endorsed a voluntary agreement between two taxi associations in terms of how a taxi rank is shared.

[54] Decision by an 'organ of state' or a 'natural or juristic person, other than an organ of state.' See section 239 of the Constitution for definition of 'organ of state.'

[55] Calibre Clinical Consultants (Pty) Ltd and Anor v The National Bargaining Council for the Road Freight Industry and Anor (2010) (5) SA 457 (SCA).

[56] See Jeeva v Receiver of Revenue Port Elizabeth (1995) (2) SA 433 (SE); Gardener v East London Transitional Local Council and Others (1996) (3) SA 99 (E); and Directory Advertising Cost Cutters v Minister of Posts, Telecommunications and Broadcasting and Others (1996) (3) SA 800 (T).

[57] Deacon v Controller of Customs and Excise (1999) (2) SA 905 (SE).

[58] Umfolozi Transport (EDMS) v Minister van Vervoerenandere (1997) (2) All SA 546 (SCA).

[59] Carephone (Pty) Ltd v Marcus NO and Others (1999) (3) SA 304 (LAC). See also Shoprite Checkers (Pty) Ltd v Ramdaw NO (2001) (3) SA 68 (LAC).

[60] See Fedsure Life Assurance Ltd and Others v Greater Johannesburg Transitional Metropolitan Council and Others (1999) (2) SA 374 (CC).

[61] The President of the Republic of South Africa and Others v South African Rugby Football Union and Others (2000) (1) SA 1 at para 141 .

[62] See Currie I and De Waal J The Bill of Rights Handbook 6th ed (Juta Cape Town 2013) 676.

[63] Azeem Hassan Walele v The City of Cape Town (2008) ZACC 11.

[64] For example, there appears to be an unending debate as to whether a freestanding environmental right binding on all nations as with the first generation rights is fully developed or still in an emergent state. See Vlavianos N "The intersection of human rights law and environmental law" in Canada Institute of Resources Law A symposium on Environment in the Courtroom: Key Environmental Concepts and the Unique Nature of Environmental Damage (Canada Institute of Resources Law University of Calgary 2012) 4.

[65] (2009) ZACC 30.

[66] See Leon Joseph and Others v City of Johannesburg and Others (2009) ZACC 30 at para 27.

[67] See Hoban v ABSA Bank Ltd t/a United Bank and Others (1999) (2) SA 1036 (SCA).

[68] 2005 (6) SA 313 (SCA) at para 21.

[69] Note that the SCA excludes the requirement of material and adverse effect on rights.
[70] Transnet Limited v Goodman Brothers (2001) (1) SA 853 (SCA) at para 9.

[71] See Currie I and De Waal J The Bill of Rights Handbook 6th ed (Juta Cape Town 2013) 659.

[72] Section 1 of PAJA.

[73] (2012) ZASCA 138.

[74] Act 36 of 2005 (hereafter "the ECA").

[75] (2012) ZASCA 138 at para 33.

[76] Section 5 (1) of PAJA.

[77] Section 5 (3) of PAJA.

[78] Section 5 (4) of PAJA.

[79] See Pieterse NO and Another v Lephalale Local Municipality (2016) ZAGPPHC at para 42.

[80] 2003 (2) SA 460 (SCA).

[81] 2003 (2) SA 460 (SCA) at para 5.

[82] 1999 (1) SA 374 (CC) at para 58.

[83] The Affordable Medicines Trust and Others v The Minister of Health of the Federal Republic of South Africa and Another (2006) (3) SA 247 (CC) at para 48.

[84] Quinot G "Substantive reasoning in administrative-law adjudication" (2010) Constitutional Law Review 112.

[85] Section 6 (1) of PAJA.

[86] Eden Security Services CC and Others v Cape Peninsula University of Technology and Others (2014) ZAWCHC 148 at para 65 . In that case, the court had to consider whether or not CPUT's decision to appoint security service providers is subject to judicial review under section 33 of the Constitution. The national legislation referred to is the Public Finance Management Act 1 of 1999, which incidentally does not cite the university. The court therefore held that universities are not included in the ambit of section 217 of the Constitution which makes provision for the procurement of goods and services by organs of state and "any other institution identified in national legislation."

[87] Currie I and Klaaren J "Introduction to the Promotion of Administrative Justice Act" in The Promotion of Administrative Justice Act Benchbook (Siber Ink Publishers Cape Town 2001) 1.30.

[88] (2005) 3 All SA 436 (SCA) at para 36.

[89] See section 6 (2) (h) of PAJA.

[90] Bato Star Fishing (Pty) Ltd v The Minister of Environmental Affairs and Tourism and Others (2004) (4) SA 490 (CC) at para 34.

[91] Bato Star Fishing (Pty) Ltd v The Minister of Environmental Affairs and Tourism and Others (2004) (4) SA 490 (CC) at para 43.

[92] Devraj Govender v The Minister of Safety and Security (2001) ZASCA 80 at para 10.

[93] See also Nomsa Ellen Dladla and Others $v$ City of Johannesburg and Others (2017) ZACC 42. 
[94] (2017) ZACC 42 at para 44.

[95] The opinion of Cameron $\mathrm{J}$ is, however, worthy of special interest. While agreeing that the rules were unreasonable, he pointed out that the test for justifiability need not always be against a law of general application. Rather, there is a need first to examine the context and requirement of the specific right underlying the rule under consideration. In the instant case, the question should be 'is the rule justified in terms of section 26 (2) of the Bill of Rights which required that the action taken must be reasonable?' That should be the "central enquiry in determining the constitutional soundness of socio-economic rights measures" (at para 63) laid down in Grootboom (2001) (1) SA 46 (CC) at para 42), TAC (2002 (5) SA 721 (CC) at para 68) and Mazibuko (2002) (5) SA 721 (CC) at para 68).

[96] See section 6 (3) of PAJA.

[97] (2005) (6) SA 182 (SCA) at para 120.

[98] See also Earthlife Africa Johannesburg $\mathrm{v}$ The Minister of Environmental Affairs and Others (2017) 2 All SA 519 (GP).

[99] See section 6 (2) (e) (iii) of PAJA.

[100] See Bato Star Fishing (Pty) Ltd v The Minister of Environmental Affairs and Tourism and Others (2004) (4) SA 490 (CC). In that case, the court considered a string of English decisions and observed that the opinion of Lord Cooke in Secretary of State for Education and Science v Tameside Metropolitan Borough [1976] 3 All ER 665 at 697, that "conduct which no sensible authority acting with due appreciation of its responsibilities would have decided to adopt" is subject to review, provided sound guidance. See also Associated Provincial Picture Houses Ltd v Wednesbury Corporation [1948] 1 KB 223 (CA), R v Chief Constable of Sussex, ex parte International Trader's Ferry Ltd [1999] 1 All ER 129 (HL) at 157, and Secretary of State for Education and Science v Tameside Metropolitan Borough [1976] 3 All ER 665 .

[101] Section 7 (1) of PAJA. Effect of delay is discussed in section 3.6 below.

[102] Section 7 (2) of PAJA.

[103] Section 8 of PAJA.

[104] See The Premier, Province of Mpumalanga v Executive Committee of the Association of Governing Bodies of State-Aided Schools: Eastern Transvaal (1999) (2) SA 91 (CC) at para 34 .

[105] The Premier, Province of Mpumalanga v Executive Committee of the Association of Governing Bodies of State-Aided Schools: Eastern Transvaal (1999) (2) SA 91 (CC) at para 41.

[106] See The Associated Institutions Pensions Fund and Others $v$ Johan van Zyl and Others (2004) (4) All SA 133 (SCA). The Constitutional Court in Bel Porto Governing Body and Others v The Premier of the Province and another (2002) (3) SA 265 at para 88, while considering item 23 (2) (b) of Schedule 6 of the Interim Constitution, held that the provision did not introduce the consideration of substantive fairness as a criterion to determine the validity of administrative action, and that any such a position would drag the courts into the consideration of political or administrative matters.

[107] Where the proceedings relate to the judicial review of an administrative action in terms of section 6 (1), section 8 (1) of PAJA gives examples of orders that is just and equitable which the court or tribunal may give.
[108] (2012) ZASCA 205.

[109] Section 8 (1) (c) (ii) of PAJA.

[110] Section 8 (1) (c) (ii) (aa) of PAJA.

[111] See Gauteng Gambling Board v Silverstar Development Ltd and Others (2005) (4) SA 67 (SCA).

[112] Minister of Environmental Affairs and Tourism v Pepper Bay Fishing (2009) (1) SA 308 (SCA).

[113] (2007) SCA 165 (RSA).

[114] Section 8 (1) (c) (ii) (bb) of PAJA.

[115] Section 38 of the Constitution guarantees inter alia, 'the right to approach a competent court, alleging that a right in the Bill of Rights has been infringed or threatened, and the court may grant appropriate relief, including a declaration of rights.'

[116] See Asla Construction (Pty) Ltd v Buffalo City Metropolitan Municipality and Anor (2017) ZASCA 23 at para 18. See also Gqwetha v Transkei Development Corporation Ltd and Others (2006) (2) SA 603 at paras 22-24.

[117] Stefaans Conrad Brümmer v Minister of Social Development and Others (2009) ZACC 21 at para 78.

[118] See section 9 (2) of PAJA. See also Opposition to Urban Tolling Alliance and Others $\mathrm{v}$ The South African National Roads Agency Ltd and Others (2013) ZASCA 148 at para 26.

[119] See The Associated Institutions Pensions Fund and Others $v$ Johan van Zyl and Others (2004) 4 All SA 133 (SCA) at para $47-48$.

[120] Section 7 (3) of PAJA.

[121] Wycliffe Simiyu Koyabe and Others v Minister for Home Affairs and Others (2009) ZACC 23 at para 35.

[122] (2007) ZACC 23.

[123] Act 66 of 1995.

[124] See Radovan Krecjir v The Minister of Correctional Services and Others (2016) (1) SACR 452 (GP) at para 18. (2016) (1) SACR 452 (GP).

[125] No 111 of 1998.

[126] (2009) ZACC 23.

[127] See Jawara v The Gambia (2000) AHRLR 107.2000 AHRLR 107.

[128] Nichol and Another v The Registrar of Pension Funds and Others (2008) (1) SA 383 (SCA) at paras 16-17.

[129] [1] Reed and Others v Master of the High Court and Others (2005) 2 All SA 429 at para 20.

[130] Sossin LM "Access to administrative justice and other worries" in Flood CM and Sossin LM Administrative Law in Context (2013) available at http://digitalcommons.osgoode.yorku.ca/scholarly works/502 (date of use 5 May 2020).

[131] Bel Porto School Governing Body and Others v The Premier of the Province and Another (2002) (3) SA 265 at para 62.2002 (3) SA 265. 
[132] Bel Porto School Governing Body and Others v The Premier of the Province and Another (2002), (3) SA 265 at para 31.

[133] Pharmaceutical Manufacturers of South Africa: In re Ex Parte Application of the President of the Republic of South Africa (2000) (3) BCLR 241 (CC) at para 44-46.

[134] See section 8 (3) of the Constitution.

[135] Section 181 (2) of the Constitution.

[136] Section 32 of the Constitution.

[137] Section 34 of the Constitution.
[138] Minister of Health v New Clicks South Africa (Pty) Ltd and Others (2006) (2) SA 311 (CC) at para 111.

[139] Section 195 (1) of the Constitution.

[140] Section 195 (3) of the Constitution.

[141] Section 195 (1) (c) of the Constitution.

[142] Section 195 (1) (f) of the Constitution.

[143] Section 195 (1) (i) of the Constitution.

[144] Section 195 (1) (e) of the Constitution. 